\title{
COMPARISON OF MATERNAL AND FOETAL OUTCOME BETWEEN INDUCED LABOUR AND SPONTANEOUS LABOUR IN LOW RISK PREGNANCY IN PRIMIGRAVIDA
}

\author{
Shivaji C. Sadekar1, Supriya Patil2, Sanjay Kumar Patil ${ }^{3}$ \\ ${ }_{13}^{\text {rd }}$ Year Junior Resident, Department of Obstetrics and Gynaecology, Krishna Institute of Medical Science, Karad, Maharashtra, India. \\ 2Professor, Department of Obstetrics and Gynaecology, Krishna Institute of Medical Science, Karad, Maharashtra, India. \\ 3Professor, Department of Obstetrics and Gynaecology, Krishna Institute of Medical Science, Karad, Maharashtra, India.
}

ABSTRACT

\section{BACKGROUND}

Induction of labour helps to reduce the number foetal deaths due to placental insufficiency caused by continuation of pregnancy beyond 40 weeks. Induction in unselected population has been associated with pronged labour, hyperstimulation, unsuccessful labour and iatrogenic prematurity. We wanted to compare maternal and foetal outcome between induced labour and spontaneous labour in primigravida low risk pregnancy.

\section{METHODS}

In this study, we included 146 women with term singleton pregnancy with vertex presentation in each group. Outcome measures were the mean duration of labour, mode of delivery and the foetomaternal outcomes.

\begin{abstract}
RESULTS
There was no difference in the mean age, height and weight in the two groups. The average GA was 38.81 weeks in spontaneous group and 40.03 weeks in induced labour. More women had spontaneous vaginal delivery among those with spontaneous labour (84.24\% versus $67.12 \%$ ). Among those who were delivered vaginally, only $8 \%$ needed instrumental delivery in both groups; rest delivered normally. The mean duration of active stage of labour was significantly more in induced labour (5.32 hours) than in spontaneous labour (4.93 hours) ( $\mathrm{p}=0.05$ ). Average duration of induction to delivery in induced group was 13.29 hours. In the present study, among both groups, it was seen that foetal distress was the common reason for LSCS, followed by failure of induction among induced labour group, followed by maternal request, followed by non-decent of foetal head and non-progress of labour and one more reason that was noticed among spontaneous labour patient was persistent occipitoposterior position.
\end{abstract}

\section{CONCLUSIONS}

No statistically significant difference was seen with regard to mean APGAR scores and maternal complications in the two groups, but rate of caesarean section increased in induced labour.

\section{KEY WORDS}

Spontaneous Labour, Induced Labour, Outcome, Singleton Pregnancy

HOW TO CITE THIS ARTICLE: Sadekar SC, Patil S, Patil SK. Comparison of maternal and foetal outcome between induced labour and spontaneous labour in low risk pregnancy in primigravida. J. Evolution Med. Dent. Sci. 2019;8(27):2149-2152, DOI: $10.14260 /$ jemds/2019/471

\section{BACKGROUND}

Labour is the process by which the foetus and placenta are delivered. During labour, there is increase in frequency, intensity and duration of uterine contraction resulting in effacement and dilation of cervix with descent of foetus through birth canal.

According to several recent studies rate of labour induction greatly increased. The prevalence of induction of labour is about $20 \%$ pregnancies in developed countries, one of the reasons for that is better planning of birth by obstetrician, patient and her family. Other reasons include the availability of FDA approved drugs for cervical ripening more liberal attitudes towards marginal or elective induction and litigious constraints. Modern obstetric techniques have in

'Financial or Other Competing Interest': None.

Submission 11-03-2019, Peer Review 16-04-2019,

Acceptance 22-04-2019, Published 08-11-2019.

Corresponding Author:

Dr. Supriya Patil,

\#261-A/5, E- Ward, Tarabai Park,

Kolhapur-416003, Maharashtra, India.

E-mail: supriyasuman@gmail.com.

DOI: $10.14260 / \mathrm{jemds} / 2019 / 471$

\section{(c) (i) $(9)$} recent year greatly increased the safety and reliability of induction of labour with result that it can be performed with greater confidence of success.

Induction of labour help to reduce the number foetal death due to placental insufficiency caused by continuation of pregnancy beyond 40 weeks. Induction in unselected population has been associated with pronged labour, hyperstimulation, unsuccessful labour and iatrogenic prematurity. As induction has both advantage and disadvantage, this study was undertaken to compare maternal and foetal outcome of both induced labour and spontaneous labour.

\section{METHODS}

The present study was an observational prospective type of cohort study the total study population consists of 292 patients. Sample size taken for convenience. All nulliparous low risk pregnancy women in latent phase of labour were included in spontaneous group while in induced group included from who was crossed expected date of delivery by using simple random technic. Group 1 is elective induction group consist of 146 patients and group 2 is spontaneous labour group consist of 146 patients. At the time of admission, the patients with exclusion criteria were not included in the 
study. ${ }^{1}$ The main objective of this study was to determine outcome associated with elective induction of labour as compared with spontaneous labour in primigravida low risk pregnancy and to study the duration of labour and mode of delivery and maternal complication in both group and also to study foetal heart rate pattern, APGAR score ( 1 and $5 \mathrm{~min}$ ), and neonatal complications in both group. It was conducted from June 2016 to June 2018

\section{RESULTS}

\begin{tabular}{|c|c|c|}
\hline Gestational Age (Weeks) & Group I & Group II \\
\hline$\leq 40$ & $79(54.11 \%)$ & $139(95.21 \%)$ \\
\hline$>40$ & $67(45.89 \%)$ & $7(4.79 \%)$ \\
\hline Total & $\mathbf{1 4 6}(\mathbf{1 0 0} \%)$ & $\mathbf{1 4 6}(\mathbf{1 0 0} \%)$ \\
\hline \multicolumn{3}{|c|}{ Table 1. Gestational Age Among the Study Population (Weeks) } \\
\hline $\begin{array}{l}\text { Average gestational age of group I was 40.03 } \pm 0.26 \text { weeks. Average weight } \\
\text { of group II was 38.81 } \pm 0.96 \text { weeks. Applying t test, p value }<0.00001 \text {. As p } \\
\text { value is <0.05, statistical significance seen. }\end{array}$ \\
\hline
\end{tabular}

\begin{tabular}{|c|c|c|}
\hline Duration of Induction to Delivery (Hours) & Group I & Percentage \\
\hline$\leq 5$ & 3 & $2.05 \%$ \\
\hline 5 to 10 & 42 & $28.76 \%$ \\
\hline 10 to 15 & 55 & $37.67 \%$ \\
\hline 15 to 20 & 44 & $30.13 \%$ \\
\hline$>20$ & 2 & $1.36 \%$ \\
\hline Total & 146 & $100 \%$ \\
\hline \multicolumn{3}{|c|}{ Table 2. Duration of Induction to Delivery in Hours } \\
\hline \multicolumn{3}{|c|}{$\begin{array}{l}\text { Average Duration of Induction to delivery (hours) of group I was } \\
13.29 \pm 4.11 \text { hours. }\end{array}$} \\
\hline
\end{tabular}

\begin{tabular}{|c|c|c|}
\hline Duration of Labour (Hours) & Group I & Group II \\
\hline$\leq 5$ & $70(47.94 \%)$ & $99(67.82 \%)$ \\
\hline$>5$ & $51(34.93 \%)$ & $.13 \%)$ \\
\hline Not reached up t & & \\
\hline Total & $146(100 \%)$ & 146( \\
\hline \multicolumn{3}{|c|}{ Table 3. Duration of Labour in Active Stage in Hours } \\
\hline \multicolumn{3}{|c|}{$\begin{array}{l}\text { Average Duration of labour (hours) of group I was } 5.32 \pm 1.76 \text { hours. } \\
\text { Average Duration of labour (hours) of group II was } 4.93 \pm 1.76 \text { hours. } \\
\text { Applying t test, } p \text { value }=0.05 \text {. As p value is }<0.05 \text {, statistical significance } \\
\text { seen. }\end{array}$} \\
\hline
\end{tabular}

\begin{tabular}{|c|c|c|c|c|}
\hline \multirow{2}{*}{$\begin{array}{c}\text { Mode of } \\
\text { Delivery }\end{array}$} & \multicolumn{2}{|c|}{ Group-A } & \multicolumn{2}{c|}{ Group-B } \\
\cline { 2 - 5 } & Number & $\mathbf{\%}$ & Number & $\mathbf{\%}$ \\
\hline Normal & 98 & 67.12 & 123 & 84.24 \\
\hline LSCS & 48 & 32.88 & 23 & 15.76 \\
\hline Total & $\mathbf{1 4 6}$ & $\mathbf{1 0 0}$ & $\mathbf{1 4 6}$ & $\mathbf{1 0 0}$ \\
\hline
\end{tabular}

Table 4. Distribution of Cases According to Mode of Delivery

$\mathrm{p}$ value $=0.0003$. As $\mathrm{p}$ value is $<0.05$ statistical significance seen.

\begin{tabular}{|c|c|c|}
\hline Vaginal Delivery & Group I (n=98) & Group II (n=123) \\
\hline Normal & $90(91.84)$ & $115(93.49)$ \\
\hline Instrumental & $8(8.16)$ & $8(6.51)$ \\
\hline Total & $\mathbf{9 8}(\mathbf{1 0 0})$ & $\mathbf{1 2 3}(\mathbf{1 0 0})$ \\
\hline \multicolumn{3}{|c|}{ Table 5. Method Used in Vaginal Delivery } \\
\hline $\begin{array}{l}\text { Applying Chi square test, p value }=0.31 \text {. As p value is }>0.05 \text {, there is no } \\
\text { statistical significance seen. }\end{array}$ \\
\hline
\end{tabular}

\begin{tabular}{|c|c|c|}
\hline Reason for LSCS & Group I (n=48) & Group II (n=23) \\
\hline Foetal distress & $11(22.91 \%)$ & $11(47.82 \%)$ \\
\hline Failure of induction & $14(29.16 \%)$ & $0(0 \%)$ \\
\hline Maternal request & $11(22.91 \%$ & $1(4.34 \%)$ \\
\hline Non decent of foetal head & $6(12.50 \%)$ & $7(30.43 \%)$ \\
\hline Non progress of labour & $6(12.50 \%)$ & $1(4.34)$ \\
\hline Persistent occipitoposterior position & $0(00 \%)$ & $3(13.04 \%)$ \\
\hline \multicolumn{3}{|c|}{ Total Table 6. Reason for LSCS } \\
\hline \multicolumn{2}{|c|}{} \\
\hline
\end{tabular}

\begin{tabular}{|c|c|c|c|c|}
\hline \multirow{2}{*}{ Groups } & \multicolumn{2}{|c|}{$\begin{array}{c}\text { APGAR score at 1 } \\
\text { Minute }\end{array}$} & \multicolumn{2}{c|}{ APGAR Score at 5 Minutes } \\
\cline { 2 - 5 } & Mean & $\begin{array}{c}\text { Standard } \\
\text { Deviation }\end{array}$ & Mean & $\begin{array}{c}\text { Standard } \\
\text { Deviation }\end{array}$ \\
\hline A & 7.38 & 1.19 & 8.63 & 1.21 \\
\hline B & 7.86 & 0.99 & 8.81 & 0.940 \\
\hline \multicolumn{3}{|c|}{ Table 7. Distribution of Cases According to Mean APGAR Score } \\
at 1 and 5 Minutes \\
\hline \multicolumn{4}{|c|}{ No statistical significance seen in both groups. } \\
\hline
\end{tabular}

\begin{tabular}{|c|c|c|}
\hline Maternal complication & Group I & Group II \\
\hline Cervical tear & $1(0.68 \%)$ & $3(2.05 \%)$ \\
\hline Paraurethral tear & $1(0.68 \%)$ & $0(0 \%)$ \\
\hline Uterine hyper & & \\
\hline No complicatio & $143(97.94 \%)$ & $143(97.94 \%)$ \\
\hline Total & $146(100 \%)$ & $146(100 \%)$ \\
\hline \multicolumn{3}{|c|}{ Table 8. Maternal Complications Among the Study Population } \\
\hline \multicolumn{3}{|c|}{$\begin{array}{l}\text { pplying Chi square test, } p \text { value }=0.39 \text {. As } p \text { value is }>0.05 \text {, there is no } \\
\text { tatistical significance seen. }\end{array}$} \\
\hline
\end{tabular}

The inclusion criteria not presenting medical/ obstetric indications for caesarean or induction and willing to give consent include Primigravida, Singleton, Vertex presentation, 37-41 weeks' gestation.

The exclusion criteria being Foetal distress, Cephalopelvic disproportion, Placenta previa type 2 posterior 3,4, Malpresentation, Multifoetal gestation, Pregnancy with medical disorder, Patients unwilling to give consent, noncephalic presentation, intrauterine growth restriction, oligohydramnios, polyhydramnios, pre-eclampsia, gestational diabetes mellitus, foetal congenital anomaly, hydrocephalus or cystic hygroma. 2,3 A written informed consent was obtained from each subject participating in the study.

\section{Data Analysis}

The collected data was compiled in Microsoft Excel 2010. Data describing quantitative measures was expressed as mean, median, mean $\pm \mathrm{SD}$, standard deviation. Qualitative type of data was expressed as percentage or proportion. Data was analysed using SPSS (Statistical Programme for Social Sciences) software 21 version, OpenEpi Software Version 2.3. For quantitative type of data test of significance applied was student $\mathrm{t}$ test and for Qualitative data Chi square test was applied.

\section{DISCUSSION}

Labour induction rate has gradually increased. Elective induction is done so that delivery happens as per physician's convenience. It is also done due to patients desire to end their pregnancy because of physical discomfort. In present age the doctor as well as the women in labour prefers to accomplish the delivery in shortest possible time, compatible with safety of mother and newborn. Hence, now a days the hopeful expectancy is replaced by an active management of labour Thus, it is imperative to determine the potential effects and outcomes associated with elective induction of Labour.

Although only limited literature is available on elective induction, its advantages and disadvantages have been described. This prospective study on the effect of elective induction of Labour on the mother and foetus have been conducted with the aim not to validate or promote elective induction but to rather identify whether electively induced Labour actually places the mother and her foetus at increased risk as compared with her spontaneous Labour group in low 
risk patients and also to determine the influence of Labour induction on caesarean delivery.

Present study showed that Average gestational age of group I was $40.03 \pm 0.26$ weeks. Average weight of group II was $38.81 \pm 0.96$ weeks. Applying t test, $p$ value $<0.00001$. As $p$ value is $<0.05$, statistical significance seen.

Study by Yadav $\mathrm{P}$ et al (4) showed that mean gestational age among spontaneous labour was $39.32 \pm 0.91$ and induced was $39.63 \pm 1.07$ weeks. $p=0.08$, shows no statistical significance. Similar study by Singh A et al(5) showed that mean gestational age among spontaneous labour was $39.37 \pm 1.46$ and induced was $39.63 \pm 1.07$ weeks. $\mathrm{p}=0.22$, shows no statistical significance.

Study by Abisowo OY et al( ${ }^{(6)}$ showed that mean gestational age at delivery was $40.25 \pm 1.33$ for the study group compared to $39.33 \pm 1.03$ for the control group showing statistically significant difference $(\mathrm{t}=8.107, \quad \mathrm{p}=<0.001)$.

There was difference in the mean gestational age which is probably because the spontaneous group population going into Labour before the expected date of delivery and the induced group, most of them being induced after crossing of their expected date of delivery.

In present study among both group I and II majority delivered vaginally as compared to LSCS. Statistical significance was also seen ( $\mathrm{p}=0.0003)$.

Study by Chaubey $\mathrm{S}$ et al(7) showed that majority had vaginal delivery in both groups. Similar results were seen in present study.

Study by Yadav $\mathrm{P}$ et al showed that majority had vaginal delivery among both the groups. $(\mathrm{p}=0.02)$, shows statistical significance.

Similar study by Singh A et al showed that majority delivered vaginal among both the groups. $(p=0.00)$.

Study by Abisowo OY et al showed that among both groups majority delivered vaginally. $\mathrm{P}<0.0001$, shows significance.

Similar findings were seen in present study.

\section{Duration of Labour in Active Stage in Hours}

- In present study Average Duration of labour (hours) of group I was $5.32 \pm 1.76$ hours.

- Average Duration of labour (hours) of group II was $4.93 \pm 1.76$ hours.

- Applying t test, $\mathrm{p}$ value $=0.05$. As $\mathrm{p}$ value is $<0.05$, statistical significance seen.

- Study by Chaubey $S$ et al showed that mean duration among induced females was $8.83 \pm 1.39$ hours and among non- induced it was $11.29 \pm 1.57 \mathrm{hrs}$.

- Similar study by Singh A et al showed that mean duration among spontaneous labour was $6.08 \pm 2.3$ and induced was $6.5 \pm 2.23$ hours. $\mathrm{p}=0.15$, shows no statistical significance.

\section{Duration of Induction to Delivery in Hours}

- Average Duration of Induction to delivery (hours) of group I was $13.29 \pm 4.11$ hours.

- Similar study by Singh A et al showed that average duration was $6.08 \pm 2.3$ hours.

Method Used in Vaginal Delivery
- Among those who were delivered vaginally in both groups, majority had normal vaginal delivery but some needed instrumental delivery (8.16\%)

- Study by Yadav P et al showed that only $6.7 \%$ needed instrumental delivery.

\section{Reason for LSCS}

- In present study among both group I and II it was seen that foetal distress was the common reason for LSCS, followed by failure of induction among group I, followed by maternal request, followed by non-decent of foetal head and non-progress of labour and one more reason was noticed among the group II females i.e. Persistent occipitoposterior position. Statistical significance was also seen $(\mathrm{p}=0.0003)$.

- Similar study by Singh A et al showed that indication for LSCS were cephalopelvic disproportion, foetal distress and failure to progress. $(\mathrm{p}=0.00)$ shows significance.

- Study by Abisowo OY et al showed that main reason for LSCS was cephalopelvic disproportion followed by foetal distress among both groups. $\mathrm{p}=0.03$, shows significance. Similar findings were seen in present study.

Duration in the present was less.

\section{APGAR Score of New-Born at $1 \mathrm{~min}$.}

- Average APGAR score of group I was $7.38 \pm 1.08$.

- $\quad$ Average APGAR score of group II was $7.86 \pm 0.73$.

- Applying t test, $p$ value $=0.09$. As $p$ value is $>0.05$, there is no statistical significance seen.

- $\quad$ Study by Chaubey $S$ et al showed that mean APGAR at 1 min among induced was $8.9 \pm 0.3$ and non-induced was $8.8 \pm 0.33$.

- Study by Yadav P et al showed that mean APGAR at 1 min among spontaneous labour was $7.1 \pm 1.22$ and induced was $7.17 \pm 1.2$. $p=0.76$, shows no statistical significance.

- Similar study by Singh A et al showed that mean APGAR at $1 \mathrm{~min}$ among spontaneous labour was $7.68 \pm 2.5$ and induced was $8.42 \pm 2.15$. $\mathrm{p}=0.00$, shows statistical significance.

- Study by Abisowo OY et al showed that mean APGAR at 1 min of control group was $6.3 \pm 1.4$ and induced group $6.2 \pm 1.4$

\section{APGAR Score of Newborn at 5 min.}

- Average APGAR score of group I was $8.63 \pm 1.04$.

- $\quad$ Average APGAR score of group II was $8.81 \pm 0.63$.

- Applying t test, $p$ value $=0.07$. As $p$ value is $>0.05$, there is no statistical significance seen.

- Study by Chaubey $\mathrm{S}$ et al showed that mean APGAR at 5 min among induced was $9.96 \pm 0.2$ and non-induced was 9.9 \pm 0.36 . $p>0.05$, no significance seen. Similar findings were seen in present study.

- Study by Yadav P et al showed that mean APGAR at 5 min among spontaneous labour was $9.38 \pm 0.8$ and induced was $9.33 \pm 0.88$. $p=0.73$, shows no statistical significance.

- Similar study by Singh A et al showed that mean APGAR at 5 min among spontaneous labour was $8.93 \pm 1.87$ and induced was $9.45 \pm 1.1$. $\mathrm{p}=0.008$, shows statistical significance. 
- Study by Abisowo OY et al showed that mean APGAR at 5 min of control group was $8.4 \pm 1.3$ and induced group $8.33 \pm 1.2$.

\section{NICU Admission}

In present study it was seen that among group I 18 new-borns needed NICU admission and 12 new-borns among group II needed NICU admission. No statistical significance was seen $(p=0.12)$. Study by Chaubey $S$ et al showed that only $2 \%$ newborn were shifted to NICU each among both groups. Study by Abisowo OY et al showed that 3.6\% among spontaneous group were admitted to NICU and $7.3 \%$ of induced group.

\section{Maternal Complication Among the Study Population}

In present study among both groups various maternal complications were seen, like cervical tear, paraurethral tear, uterine hyperstimulation. No statistical significance was seen $(\mathrm{p}=0.39)$. In study by Yadav P et al it was seen that cervical tear was in only induced case $\mathrm{p}=1$.

\section{CONCLUSIONS}

A number of studies have examined the outcome of elective induction and most have concluded that there is litter difference in outcomes between those patients who undergo elective induction and those who have spontaneous labour. We conclude from this study that while induced labour may increase chances of caesarean section, it does not adversely affect maternal outcome and foetal outcome. However, increased risk of caesarean section by induction of labour should be a part of informed consent, discussion with patient who needs induction is important. The patient may very well choose to delay, avoid or accept induction.

\section{REFERENCES}

[1] Donald I. Management of labour. In: Mishra R, edr. Practical obstetric problems. $7^{\text {th }}$ edn. New Delhi: BI Publication Pvt. Ltd., 2014;24:466-80.

[2] Suchika G, Usha S, Premlata M, et al. To study the fetomaternal outcome and progress of labour among induced versus spontaneous labour in nulliparous women. Sch J App Med Sci 2014;2(5A):1577-80.

[3] Stock SJ, Ferguson E, Duffy A, et al. Outcomes of elective induction of labour compared with expectant management: population based study. BMJ 2012;344:e2838.

[4] Yadav P, Verma M, Harne S, et al. Comparison of spontaneous labour with induced labour in nulliparous women using modified WHO partograph. Int J Reprod Contracept Obstet \& Gynecol 2016;5(11):4005-8.

[5] Singh A, Rao SB, Sherigar B, et al. Comparison of progress of labour and maternofoetal outcome among induced versus spontaneous labour in nulliparous women using modified WHO partograph. Int J Reprod Contracept Obstet \& Gynecol 2018;7(2):415-8.

[6] Abisowo OY, Oyinyechi AJ, Olusegun FA, et al. Fetomaternal outcome of induced versus spontaneous labour in a Nigerian Tertiary Maternity Unit. Trop J Obstet \& Gynaecol 2017;34(1):21-7.

[7] Chaubey S, Kanti Y, Sandhya K, et al. Maternal \& foetal outcome after induction and expectant management of Labour in primigravida and multigravida. Imperial Journal of Interdisciplinary Research (IJIR) 2016;2(8):706-9. 